\title{
ДиСКУССИ Я
}

УдК 94(5)+811.512

DOI: $10.22378 / 2313-6197.2018-6-3.596-617$

\section{О НОВЫХ ТЕНДЕНЦИЯХ В ИЗУЧЕНИИ ИСТОРИИ МОНГОЛЬСКИХ ЗАВОЕВАНИЙ: НА ПРИМЕРЕ СТАТЬИ СТИВЕНА ПОУ «ПОСЛЕДНЯЯ КАМПАНИЯ И СМЕРТЬ ДЖЕБЕ-НОЙОНА»*}

\author{
Д.М. Тимохин ${ }^{1}$, В.В. Тишин ${ }^{2}$ \\ ${ }^{1}$ ФГБУН Институт востоковедения РАН \\ Москва, Российская Федерачия \\ horezm83@mail.ru \\ ${ }^{2}$ Институт монголоведения, буддологии и тибетологии СО РАН \\ Улан-Удэ, Российская Федерачия \\ tihij-511@mail.ru
}

Цель исследования: недавно вышедшая блистательная статья Стивена Поу «Последняя кампания и смерть Джебе-нойона» позволила открыть дискуссию по ряду вопросов, связанных с монгольскими походами на Кавказ и Восточную Европу в первой половине 20-х гг. ХІІІ вв. В частности, автор отстаивает тезис о завоевательном характере похода корпуса во главе с полководцами Чингиз-хана Джэбэ-нойоном и Субэдэй-багатуром, а также выдвигает гипотезу о гибели первого из упомянутых полководцев в ходе этого мероприятия, конкретно в битве на р. Калке против кыпчакских и русских войск. Авторы данной статьи не могут согласиться с доводами венгерского коллеги и считают возможным привести ряд контраргументов против обеих его позиций.

Материалы исследования: авторы стремились использовать весь массив доступных письменных источников, которые позволили бы внести корректировки в решение вопросов, поднятых С. Поу. Прежде всего, это сочинения персидских авторов (Ан-Насави, Джувейни, Рашид ад-Дин ат-Табиб), грузинская «Столетняя хроника», армяноязычное сочинение «Хроника» Мхитара Айриванеци, древнерусские летописи (прежде всего, Первая Новгородская младшего извода, Лаврентьевская и Софийская первая). Кроме того, были использованы лингвистические данные, представленные данными тюркских, монгольских и славянских языков.

Результаты исследования и научная новизна: главным контраргументом против мнения оппонента о завоевательном характере похода монгольского корпуса является неполнота привлеченного им фонда источников, а также отсутствие в наиболее информативных из них каких-либо прямых или косвенных данных, позволяющих подкрепить его гипотезу. Версия о гибели Джэбэ-нойона при Калке, осно-

* Работа Тимохина Д.М. выполнена при поддержке гранта РГНФ № 16-01-50028ОГН; Работа Тишина В.В. выполнена при поддержке Комплексной программы фундаментальных исследований СО РАН ХІІ.191.1.2. Межкультурное взаимодействие, этнические и социально-политические процессы в Центральной Азии, № AАAА-А17$117021310264-4$.

() Тимохин Д.М., Тишин В.В., 2018 
ванная на мнимом отождествлении его имени с Гемябеком древнерусских летописей, не имеет абсолютно никаких лингвистических доказательств.

Ключевые слова: Южный Кавказ, Джэбэ, монгольские завоевания, кыпчаки, битва при Калке, тюркская филология

Для циитирования: Тимохин Д.М., Тишин В.В. О новых тенденциях в изучении истории монгольских завоеваний: на примере статьи Стивена Поу «Последняя кампания и смерть Джебе-нойона» // Золотоордынское обозрение. 2018. Т. 6, № 3. C. 596-617. DOI: 10.22378/2313-6197.2018-6-3.596-617

\title{
ON NEW TRENDS IN THE STUDIES OF THE HISTORY OF THE MONGOL CONQUESTS: BASED ON THE EXAMPLE OF STEPHEN POW'S ARTICLE “THE LAST CAMPAIGN AND DEATH OF JEBE NOYAN"*
}

\author{
D.M. Timokhin ${ }^{1}$, V.V. Tishin ${ }^{2}$ \\ ${ }^{I}$ Institute of Oriental studies of the RAS \\ Moscow, Russian Federation \\ horezm83@mail.ru \\ ${ }^{2}$ Institute for Mongolian, Buddhist and Tibetan Studies \\ of the Siberian Branch of the RAS \\ Ulan-Ude, Russian Federation \\ tihij-511@mail.ru
}

\begin{abstract}
Research objectives: A recently published brilliant article by Stephen Pow, "The Last Campaign and Death of Jebe Noyan," opened a discussion on a number of issues related to the Mongol campaigns in the territory of Caucasus and Eastern Europe in the first half of the 1220s. In particular, the author defends the thesis that the raid of the army led by Jebe Noyan and Sübe'etei Ba'atur was intended as a conquest. He also hypothesizes that the death of the first of the aforementioned generals occurred during that campaign, specifically in the Battle of the Kalka River against the Kipchak and Russian Princes' troops. The authors of this article cannot agree with the arguments of the Hungary-based scholar and attempt to bring a number of counter-arguments against both of his positions.

Research materials: The authors tried to use the whole array of available written sources to make adjustments to the solution of the questions raised by S. Pow. First of all, these are the works of Persian authors (al-Nasavi, Juvayni, Rashid al-Din al-Tabib), the "Georgian Chronicle of a Hundred Years", the "Chronicle" written in Armenian by Mxitar Airivanetsi, Old Russian Chronicles (foremost among them, the Novgorod First Chronicle, Laurentian Chronicle and Sofia First Chronicle). In addition, linguistic materials represented by the data of the Turkic, Mongolian and Slavic languages were used too.

Research results and novelty: The fact that Stephen Pow did not use all available sources is the main counterargument against the assertion about the conquering nature of the Mongol military campaign. In addition, it is not possible to find any direct or indirect data allowing one to support his hypothesis. The interpretation of the death of Jebe Noyan

* The work by D.M. Timokhin was supported by the grant of the Russian Humanitarian Scientific Foundation № 16-01-50028-ОГН. The work by V.V. Tishin was supported by the Comprehensive Program of Basic Research of Siberian Branch of the Russian Academy of Sciences XII.191.1.2. Intercultural interaction, ethnic and socio-political processes in Central Asia, № AAAA-A17-117021310264-4.
\end{abstract}


during the Battle of the Kalka River, based on the visionary identification of his name with Gemyabek recorded in Old Russian chronicles, has no linguistic evidence absolutely.

Keywords: South Caucasus, Jebe, Mongol conquests, Kipchaks, Battle of the Kalka, Turkic philology

For citation: Timokhin D.M., Tishin V.V. On New Trends in the Studies of the History of the Mongol Conquests: Based on the Example of Stephen Pow's Article "The Last Campaign and Death of Jebe Noyan". Zolotoordynskoe obozrenie=Golden Horde Review. 2018, vol. 6, no. 3, pp. 596-617. DOI: 10.22378/2313-6197.2018-6-3.596-617

В истории завоевательных походов Чингиз-хана и его наследников, а также формирования Монгольской империи, несмотря на обширный и разносторонний исследовательский опыт, продолжает существовать определенное количество «белых пятен». В связи с этим любая попытка дать ответ на тот или иной сложный вопрос, выдвинуть гипотезу относительно мало или вовсе неизученных аспектов истории монгольских завоевательных походов и формирования империи Чингиз-хана заслуживает пристального внимания со стороны научной общественности. Ярким примером нового подхода к решению подобного рода научных задач является статья Стивена Поу «Последняя кампания и смерть Джебе-нойона» [59] ${ }^{1}$, опубликованная в переводе на русский язык также в журнале «Золотоордынское обозрение» $[28]^{2}$ и сразу же привлекшая внимание исследователей, как поднятой в ней проблематикой, так и авторскими выводами. Безусловно, пройти мимо этого исследования не смогли и авторы представленной ниже статьи, чья рецензия направлена не только в адрес Стивена Поу, но и всех исследователей монгольской военной и политической истории в Средние века. Нам, прежде всего, хотелось бы не только начать научную дискуссию вокруг указанной выше статьи, но и вновь обратить к обозначенному исследовательскому полю и тем лакунам, которые оно содержит и которые требует от нас новых специальных исследований.

Для начала скажем несколько слов о значимости научной проблематики, к которой обращается в своей работе Стивена Поу. Безусловно, прежде всего, необходимо отметить, что сама по себе личность Джэбэ-нойона долгое время оставалась обойденной специальным вниманием исследователей, на что указывает и сам автор статьи: «не существует ни одного исследования ни на одном языке, которое рассматривало бы личность и судьбу Джебе-нойона в качестве специфичной темы» [28, с. 700]. При этом из всей биографии представленной исторической личности наибольший интерес автора прикован к обстоятельствам гибели Джэбэ-нойона, о чем исторические источники, как указывает Стивен Поу, предоставляют скудную и крайне противоречивую информацию $[28$, с. 700$]$. Учитывая данные обстоятельства и саму значимость данной исторической личности в контексте истории монгольских завоеваний и формирования монгольской империи, как уже указывалось нами выше, любое специальное исследование биографии Джэбэ-нойона и особенно обстоятельств его смерти следует считать весьма значимым событием в исторической науке.

\footnotetext{
1 Здесь и далее авторы используют вариант транскрипции «Джэбэ», сохраняя написание «Джебе» при цитировании перевода статьи С. Поу, которое в ней дано.

2 Здесь и далее даются ссылки именно на это русскоязычное издание.
} 
Заранее хотелось бы отметить, что в данной рецензии нами основное внимание будет сосредоточено на анализе того, как Стивен Поу решил поставленные перед собой исследовательские задачи и к каким важнейшим результатам пришел по итогам исследования. Уже в самом начале своей работы автор обозначает не только то, что его интересует в первую очередь в рамках представленного исследования, но и важнейшие результаты, которые мы позволим себе процитировать. «Главным открытием исследования является то, что «Новгородская Первая летопись» описывает гибель Джэбэ-нойона за неделю до битвы на Калке. Это утверждение выдвигается впервые, поскольку ранее было распространено мнение, что Джэбэ умер после его мнимого возвращения в Монголию. Другим важным открытием является то, что первичные источники не подтверждают мнения о том, что кампания Джэбэ и Субэдэя вокруг Каспия в 1221-1223 годах была всего лишь разведывательным набегом: источники скорее склонны свидетельствовать, что их главной целью были завоевания» [28, с. 698]. С нашей стороны, как уже говорилось, критическому рассмотрению будут подвергнуты именно эти два положения, выделенные самим автором в качестве результатов исследования - датировка и обстоятельства смерти Джэбэ-нойона и оценка деятельности войск Джэбэ и Субэдэя в 1221-1223 гг. На других разделах представленного исследования мы остановимся в значительной степени более кратко и укажем лишь их ключевые особенности и приведем отдельные критические замечания по ним.

Сама статья состоит из вводной части, где автор обозначает цель и задачи исследования, а также его актуальность, что, впрочем, как уже говорилось выше, не может вызывать существенных вопросов - любое специальное исследование биографии Джэбэ-нойона с учетом состояния современной историографии проблемы актуально само по себе. Далее следует раздел статьи «Лакуны и пропуски: проблемы материала источников по Джебе-нойону», в котором автор анализирует источниковую базу собственного исследования, сосредотачивая особое внимание на выделении лакун в описании биографии Джэбэ-нойона в рамках различных исторических источников. Здесь, прежде всего, стоит отметить достаточно подробный анализ информации об указанной исторической личности в китайских источниках [28, с. 701-702], с выделением противоречий и откровенных лакун. Впрочем, данный раздел имеет и недостатки - по сути это не анализ всей источниковой базы, а лишь отдельных памятников, в связи с чем из арабо-персидских сочинений здесь можно увидеть лишь указание на труд Рашид ад-Дина [28, с. 702], а о памятниках грузинской и армяноязычной средневековой историографии речь не идет вовсе. При этом в дальнейшем в тексте исследования можно увидеть ссылки на другие памятники, кроме указанных выше, арабо-персидской историографии, а также на сведения из грузинских и армяноязычных источников. Подобная избирательность автора в данном разделе никак им не поясняется, что может вызвать вопросы у читателя: почему не анализируется сведения о Джэбэ-нойоне в составе других исторических источников? Отметим, что в исследовании в принципе отсутствует попытка систематизации источников по проблеме и анализ эволюции сведений о Джэбэ-нойоне в средневековых исторических сочинениях. По сути, автор пытается выстроить представление о лакунах в биографии указанной исторической личности на ограниченном круге источников. 
Следующий за этим раздел «Жизнь и военные кампании Джебе-нойона до 1223 года» предлагает подробное описание биографии указанной исторической личности, начиная с момента его перехода на службу к Чингиз-хану и вплоть до битвы на Калке 1223 г. В рамках этого раздела для нашей рецензии особый интерес будет представлять та его часть, где автор дает оценку деятельности войск Джэбэ и Субэдэя в 1221-1223 гг. Здесь ключевым утверждением автора следует признать то, что «на мой взгляд, можно сказать с уверенностью, что популярная в современных исследованиях тенденция называть кампанию Джэбэ и Субэдэя «набегом» или «разведкой боем» противоречит утверждениям источников» $[28$, с. 706$]$. С точки зрения автора, поход отрядов Джэбэ и Субэдэя следует считать попыткой завоевания новых территорий, в том числе в пределах Ирана и Южного Кавказа. Для доказательства этого постулата Стивен Поу использует труд Рашид ад-Дина, который с его точки зрения содержит послание Джэбэ и Субэдэя, которое «отображает их намерение осуществить завоевание как можно большего числа регионов в течение нескольких лет до возвращения в Монголию» [28, с. 706]. Однако сам текст послания, на которое опирается автор, не содержит прямых указаний на это: «Султан Мухаммед умер, а сын его Джелал-ад-дин бежал и пришел в ту страну. Теперь мы, освободив сердце от [заботы] о них, согласно требованию, которое было определено приказом Чингиз-хана, бог даст, сможем прибыть в Могулистан, [но] это ведает мощь великого господа и счастье Чингиз-хана!» [30, с. 226]. Гораздо более убедительным в рамках авторской концепции выглядело бы следующее описание из труда того же Рашид адДина. «В результате всего, когда они [Джэбэ и Субэдай] приступили к завоеванию Ирака, то сначала взяли Хар [?] и Семнан, оттуда они подошли к городу Рею и учинили [там] избиение и грабеж. [Отсюда] двинулись на Кум, [где] перебили всех тамошних жителей, а детей увели в полон. Оттуда [монголы] пошли в Хамадан. Сейид Маджд-ад-дин Ала-ад-доулэ подчинился и прислал подношения, [состоящие] из верховых лошадей и одежд, и согласился на [принятие монгольского] правителя [шихнэ]» [30, с. 226].

Остается загадкой, в связи с чем сведения из более позднего источника, при отсутствии прямых указаний из более ранних памятников, позволяют автору быть столь уверенным в «завоевательном» характере действий войск Джэбэ и Субэдэя. Надо отметить, что автор в целом крайне избирательно подходит к выбору источников для описания тех или иных исторических событий, однако на чем основан этот выбор также остается загадкой: в частности, при описании событий на Южном Кавказе и сопредельных регионах Стивен Поу использует сведения из труда Вардана Аревелци, при этом гораздо более значимое для анализа монгольского вторжения в пределы Кавказа сочинение Киракоса Гандзакеци «История» не упоминается ни в тексте статьи, ни в списке использованной литературы. О существовании же иных памятников армяноязычной историографии монгольского вторжения на Южный Кавказ и сопредельные регионы автор статьи старательно умалчивает, хотя можно было бы обратиться и к «Летописи» [2, с. 34-43] епископа Степаноса, и к «Летописи» Себастаци [2, с. 23-34]. Грузинский же исторический источник, а именно «Столетняя хроника» или «Хронограф» XIV в. [1; 6; 38], упоминается автором лишь единожды, да и то без указания названия, отсылая 
при этом читателя ко всему тексту «Картлис Цховреба» [28, с. 707]. Подобная избирательность в отношении источников и отсутствие обращение ко всему массиву памятников во многом помогает автору выстроить свою концепцию относительно действий войск Джэбэ и Субэдэя, которая при ближайшем рассмотрении не выглядит такой уж убедительной.

Так, в качестве доказательства собственной концепции Стивен Поу старательно приводит сведения из Ибн ал-Асира, Джувейни и Рашид ад-Дина, где указывается на назначение наместников в покоренные, сдавшиеся без боя города, в чем, с его точки зрения, следует видеть важнейшее доказательство «завоевательного» характера действий монголов. Ответ на вопрос, почему данный факт следует считать доказательством именно «завоевательного» характера похода Джэбэ и Субэдэя, а не скажем попытку обеспечить себе безопасный путь отступления, в случае невозможности по тем или иным причинам дальнейшего продвижения в западном направлении, остается только гадать. Да и о каком завоевании могла идти речь, если источники не сообщают нам ничего относительно собственно монгольских или подчиненных монголам гарнизонах в завоеванных городах по пути следования войск Джэбэ и Субэдэя?! В этом случае назначение монгольского наместника становится не более чем символическим жестом, поскольку реального и долговременного подчинения того или иного города просто не происходит в виду отсутствия у такого наместника военной силы, на которую он мог бы опереться. При этом следует более внимательно рассматривать текст основного, как следует из текста статьи, источника для Стивена Поу, а именно труда Рашид ад-Дина.

В тексте этого исторического источника можно легко найти и сравнить действия монгольских отрядов по отношению к сдавшимся городам в ходе завоевания государства Хорезмшахов и упомянутых выше отрядов Джэбэ и Субэдэя. В обоих случаях, чаще всего монголы оставляли в городе своего наместника, однако в ходе монголо-хорезмийской войны такие города отдавали часть населения в хашар (подробнее см.: [34]), как это было с Зарнуком [30, с. 204], или же предоставляли часть войска в помощь монголам, как это было с городом Нур [30, с. 204]. Субэдэй и Джэбэ либо просто оставляли своего наместника, как это было в Балхе [30, с. 210], либо оставляли грамоту и довольствовались фуражом и формальным подчинением, как это было в Нишапуре [30, с. 211]. Сам персидский историк указывает на особенность продвижения отрядов Джэбэ и Субэдэя вглубь хорезмийских территорий «повсюду, где выходили им навстречу с подчинением, они щадили, а всех, кто сопротивлялся, они уничтожали» [30, с. 211]. При этом Стивен Поу не обозначает, что в тексте источника кампания Субэдэя и Джэбэ в Западном Иране и Южном Кавказе существенно отличается от действий этих же отрядов в ходе поисков хорезмшаха Ала ад-Дина Мухаммада. В первом случае, а о втором нами было сказано выше, отряды Джэбэ и Субэдэя чаще всего разоряли и уничтожали города на своем пути, и лишь в двух случаях этого не происходило - в отношении Хамадана и Табриза. Первый город действительно получил наместника от Джэбэ и Субэдэя, а точнее им стал местный сейид [30, с. 227], в отношении же Тебриза не произошло и этого: монголы довольствовались данью, причем взяли ее дважды [30, с. 227].

$\mathrm{C}$ нашей точки зрения, сочинения Рашид ад-Дина не подтверждает идеи Стивена Поу и не предоставляет достаточного фактического материала для ее 
доказательства. Можно лишь указать на то, что действия отрядов Джэбэ и Субэдэя представляли собой не одну, а две разные военные кампании: первая из них закончилась со смертью хорезмшаха Ала ад-Дина Мухаммада в 1220 г., и, исходя из текста Рашид ад-Дина, вполне могла носить и завоевательный характер. Вторая же, включающая в себе поход на Кавказ и далее в половецкие степи исходя из текста того же памятника отличалась по характеру действий монгольских отрядов, и веских доводов в пользу его завоевательного характера мы не находим. При этом Стивену Поу следовало привлечь для описания действий отрядов Джэбэ и Субэдэя в Иране и на Кавказе весь массив исторических источников, что, вполне вероятно, изменило бы авторский взгляд на указанную проблему. Так, в труде ан-Насави нет ни одного указания на наместников, поставленных Джэбэ и Субэдэем, хотя автор был не просто современником событий, но и непосредственно присутствовал, как в Иране и так на Кавказе. Вышеуказанный пример из Рашид ад-Дина об оставлении монгольскими военачальниками наместника в Хамадане опровергается тем же ан-Насави указанием на то, что «Йеке-нойан и Сюбетей-бахадур, захватив Хамадан в начале выступления татар, вымели начисто богатство города и изгнали жителей оттуда, и не осталось там ни пользы, ни силы» (цит. по: [16, с. 177]).

Таким образом, сами по себе арабо-персидские источники не содержат убедительных доказательств в пользу точки зрения Стивена Поу, при этом сравнение действий монгольских военных отрядов Джэбэ и Субэдэя с реалиями монголо-хорезмийской войны также свидетельствуют не пользу авторской концепции. Важно отметить, что сдавшиеся монголам города получали наместника в годы указанной выше войны, в большинстве случаев, из числа доверенных лиц на монгольской службе, в то время как Джэбэ и Субэдэй прибегали к использованию местных кадров, что также является важным отличием. Как было указано выше, более ранние памятники во многом также противоречат концепции Стивена Поу, а, исходя из текста, столь часто используемого автором Рашид ад-Дина, можно сделать выводы о разнице действий отрядов Джэбэ и Субэдэя до и после 1220 г. Резюмируя анализ этой части статьи, можно сказать, что более внимательное отношение ко всему массиву исторических источников могло бы как минимум скорректировать предложенную автором концепцию. Впрочем, стоит отметить и тот факт, что в этой части исследования хотелось бы видеть и более внимательное отношение к историческим реалиям. Так, Стивен Поу указывает на то, что «они (т.е. монголы - npuм. aвm.) обогнули Армению и Грузию, чтобы избежать столкновения с большим числом скопившихся там врагов» $[28$, с. 706]. Если под Грузией и Арменией в данном случае понимаются политонимы, то автору следовало бы знать, что государства «Армения» в тот период в пределах Кавказа не существовало. В случае, если имелось в виду что-то иное, то требуется как минимум объяснение этого, поскольку под термином «Грузия» в данном разделе автор, если следовать тексту, имеет в виду именно государство. Такое отношение к историческим реалиям Южного Кавказа в указанный исторический период со стороны специалиста выглядит как минимум странным.

Последующие разделы представленной статьи «Кампания 1223 года и обстоятельства смерти Джебе-нойона» и «Лингвистические и косвенные доказательства того, что Гемябег является Джебе-нойоном» хотелось бы рас- 
смотреть вместе, поскольку именно в них автор обстоятельно выстраивает собственную концепцию гибели Джэбэ-нойона, что, по большому счету и является главной целью представленного исследования. Прежде всего, отметим тот факт, что для авторской концепции гибели Джэбэ в ходе военных действий, предшествовавших битве на Калке 1223 г., имеются опровержения как источниковедческого, так и лингвистического характера. Для начала отметим некоторые лакуны по данному вопросу в исторических памятниках. В источниках имеются непрямые данные о том, что Джэбэ вернулся из этого похода, которые отмечает и Стивен Поу, однако, не имеет возможности ничего противопоставить им, кроме логических заключений, опирающихся на уже сделанное им отождествление [28, с. 716-717]. «Юань ши» 元史 (цз. 120, с. 15a) в биографии Исмаила (Хэ-сы-ма-ли 曷思麦里) сообщается, что войска под командованием Джэбэ (Чжэ-бо 哲伯) завоевали страну (го 国) правителя (чжу 主) Мстислава (Ми-чжи-сы-ла 密只思臘), Джэбэ (Чжэ-бо 哲伯) приказал Исмаилу (Хэ-сы-ма-ли 曷思麦里) представить Мстислава (Ми-чжи-сыла 密只思臘) «наследнику престола» (тай-изы 太子) Джучи (Чжу-чжи 誅之), потом его казнили [55, S. 204-205; 56, s. 346, 350, note 20; 9, с. 35; 36, с. 522]. Повествование о Джэбэ заканчивается фразой: изюнь хай чжэ-бо uзу 軍還哲伯卒 (ср.: [28, с. 716, прим. 34]), что в русскоязычном буквальном переводе Е.И. Кычанова: «Армия вернулась. Чжэбе скончался» [9, с. 35]; в синтаксически адаптированном переводе Р.П. Храпачевского: «По возвращении войска Чжэбэ умер» [36, с. 522]; ср. адаптированный перевод Б. Ӧгеля на турецкий язык: «<...onların da maglup ederek> geriye döndüğü zaman Cäbä ölmüştü» [56, s. 346]. В этом случае интерпретация текста как указание на одновременность или последовательность событий не противоречит нормам синтаксиса китайского языка, но с формальной точки зрения сами контексты упоминания в одном и том же тексте (биография Исмаила (Хэ-сы-мали 曷思麦里)) Джэбэ указывают на то, что он, по крайней мере, был жив после столкновения с русскими, независимо от того, погиб ли он в самом этом походе или умер по возвращению войска.

У Рашид ад-Дина имеется беглое указание на то, что Джэбэ и Субэдэй прибыли ко двору ха'ана Угэдэя и засвидетельствовали ему свое почтение [29, с. 98-99; 63, p. 41]. В источнике [71, ص vr]:

$$
\begin{aligned}
& \text { جبه و سوباتاى كه به ايران زمين آمده بودند و به راه تيمور قهلفه ناز كثتنه ، به بتدكي اوكناى } \\
& \text { قآن رسيدند و اولجاميشى كرد }
\end{aligned}
$$

Как видно из этого отрывка сочинения Рашид ад-Дина, на которого неоднократно ссылается сам Стивен Поу, персидский историк подчеркивает возвращения обоих полководцев (третье лицо, множественное число глагольной формы). Отчего можно пренебречь прямым указанием исторического источника, когда его автор был прекрасно осведомлен обо всех перипетиях похода Джэбэ и Субэдэя, остается только гадать. Так или иначе, перед нами прямое указание на то, что в ходе Западного похода Джэбэ не погиб. 
Возможно, этот же мотив перекочевал к Абу'л-Гази в «Шаджара-йи тюрк ва могул», где в качестве участника погони за хорезмшахом упомянут один Джэбэ (ср. в «Шаджара-йи таракима» и Джэбэ, и Субэдэй $[8$, с. 44 (рус. перевод), r·, §300 (тюрк. текст)]), который завоевал Иран, Азербайджан и Грузию, прошел Тимур Капу (Железные ворота), разорил Дагестан, земли черкесов и кыпчаков, затем пересек Итиль (Волгу) и Йаик (Урал) и после четырехлетнего похода вернулся к Чингиз-хану, присоединившись к

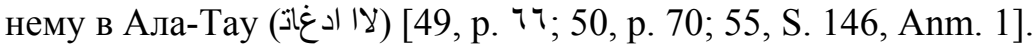

При любых обстоятельствах игнорировать свидетельства этих трех (или, учитывая зависимость Абу'л-Гази от Рашид ад-Дина, - двух) источников нельзя, опираясь лишь на логические соображения. Потому, даже не вдаваясь в дискуссию о том, кто из двух полководцев, Джэбэ или Субэдэй, командовал походом, а кто находился в более подчиненном положении, и также не вдаваясь в обсуждение предлагаемой Стивеном Поу реконструкции битвы при Калке, мы обратим внимание на саму возможность сопоставления имен Джэбэ-нойона и «воеводы» Гемябека. Этот момент сам по себе должен требовать очень обстоятельную аргументацию, подразумевающую довольно обширную источниковедческую работу и более пристальное внимание к лингвистическим вопросам.

Следует рассмотреть сами случаи упоминания имени монгольского «воеводы» в древнерусских летописях. Мы встречаем следующие формы имени (приводятся падежные формы - творительный и винительный, как в оригинале):

Суздальская летопись по Лаврентьевскому списку: Гемнбъькомъ, Семецбгкать [19, стб. 506, прим. 4];

Софийская первая летопись: Сгемябъкомъ, Сгемябъга [21, с. 204] (ср.: [19, стб. 506, прим. 4]).

Тверская летопись: Гемябъкомъ, Гемябъка [23, с. 340].

Младшая Новгородская летопись первого извода: Гемябъгомъ, Гемябъга $[17$, c. 266$]$

Львовская летопись: Гомябъгомъ, по списку Н.А. Львова - Гамябекомъ [25, с. 152 , прим. 14].

Ермолинская летопись: Гомябгькомъ [26, с. 70].

Если принять во внимание мнение о том, что начало описания битвы н Калке в Лаврентьевской и Новгородской летописях восходят к одному источнику, судя по всему, южно-русскому, где при относительной краткости Лаврентьевской, Младшая Новгородская первого извода характеризуется большими подробностями в самом повествовании, обнаруживая ряд симпатий к князю Мстиславу Удалому, Софийская первая летопись, хотя при ее составлении использовались две выше упомянутые, содержит независимые фрагменты $[10$, с. $66 ; 11$, с. $34 ; 47 ; 5$, с. 13,14$]$, Тверская в ранней части зависима от суздальско-новгородской традиции, Ермолинская и близкая к ней Львовская являются в интересующей нас части позднейшими компиляциями $[11$, c. 51-52, 74, 89, 99, 154-155, 231], то мы должны учитывать все три формы: *Гемабъкъ, *Семенабъкъ (Лавр.), *Сгемябъкъ, *Сгемябъгъ (Соф. I), *Гемябъгъ (Новг.). Что касается конечного звука, то, судя по зафиксированному в Codex Cumanicus beg 'princeps', bej ‘baron' [41, 104, 105, 300 o. (Index); 43, s. 54], в исходном звучании должна быть именно эта форма со звонким гласным, что отражено в Новгородской летописи. Впрочем, в других случаях 
летописец или его русскоговорящий источник могли не обратить внимания на такие частности, руководствуясь принципом «как слышится, так и пишется». В любом случае, эта деталь не столь существенна и мало что может дать. Иной вопрос - вариации начальной формы: *ГемА- $/{ }^{*}$ Гемя- ${ }^{*}$ СеменА${ }^{*}$ Сгемя-. Возможно допущение, что в основе разночтения в Лаврентьевской летописи лежит непонимание автором текста или на каком-то этапе переписчиком содержания повествования сюжета о Калке, что допустимо, учитывая количество описок в источнике [10, с. 58-59, 62], и точно так же только теоретически можно предположить, что составитель Софийской первой летописи осознанно или нет, но создал некий гибрид, комбинируя оба источника: *Гемл- $/{ }^{*}$ Гемя- $>{ }^{*}$ Сгемя- <

Что касается Джэбэ, оригинальное среднемонгольское звучание имени рассматриваемого персонажа находит параллели в ряде монгольских языков: письм.-монг. jebe 'Kriegsgerät, Waffen', халх.-монг. zew 'arrowhead, spearhead'; бур. zebe 'Spitze; Schneide'; ордос. jiwe 'pointe de flèche'; ойрат. zebe 'lance, weapon', zebseg 'weapons'; калм. zer zew 'Waffen, Bewaffnung; Instrument (der Handwerker), Zubehör; Hausgerät' [66, s. 272]. Это же звучание отражают различные варианты, приводимые в «Юань ши» 元史 (Чжэ-бе 哲别, пиньин. zhé-bié; Чжэ-бе 遮别, пиньин. zhē-bié; Шэ-бе 闍别, пиньин. shé-bié; Чжэ-бу на-янь 折不那演, пиньин. zhé-bù nà-yăn; Чжэ-бо 哲伯, пиньин. zhé-bó; Чжи-бе 只别, пиньин. zȟ̆-bié; Чжэ-би на-янь 者必那演, пиньин. zhě-bì nà-yăn; [*Чжэ-]бе на-янь 别那顏, пиньин. bié nà-yán; Чжэ-бе-эр 折别兒, пиньин. zhébié-ér; Чжэ-бай 柘柏, пиньин. zhè-băi) и «Мэн да бэ-лу» 蒙䩼備錄 (Чжэ-бо

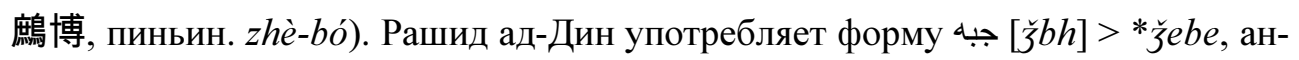
Насави, Джувейни, Джузджани - يمه $[y m h]>$ *уämä, что П. Пельо назвал «тюркизированной» формой [48, p. 154-156] (см. также: [44, p. 142-143, note 1,$373 ; 51 ; 28$, с. 710]). У Абу'л-Гази, зависимого от Рашид ад-Дина: جبه [క̌bh] («Шаджара-йи таракима») [8, с. r·, §300 (тюрк. текст)], џپ [čph] («Шаджара-йи тюрк ва могул») [49, р. т7].

В армяноязычной «Хронике» Мхитара Айриванеци называется SLlpt [70, th 65], т.е. Джэбэ [2, с. 89]. В анонимном грузинском сочинении XIV в., «Столет-

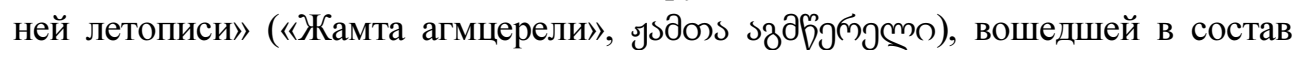
хроники «Картлис цховреба», дан следующий пассаж: «Чингиз-каэн отправил (в погоню) за ним двух предводителей - Иаму и Салпиана, коих грузины именуют Себа и Джебо» [7, с. 336], т.е. здесь названы os $\partial s$ и lssmozos6- $о$, что, как

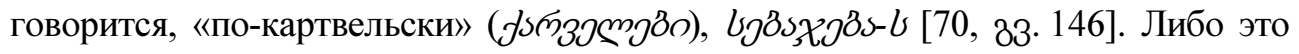

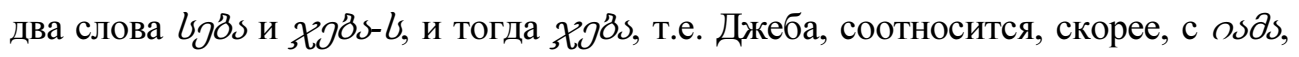
т.е. Иама, хотя не исключено, что составитель хроники вообще плохо понимал, о чем идет речь, и привел все три известные ему формы, если не четыре. В этом случае не только $b$ gds, т.e. Себа, заслуживает отдельного внимания (<*sebä?). Дело в том, что $\measuredangle s$ mozos6 едва ли является искаженной формой исходного Sübe'etei $(<*$ sübê) [66, S. 660], а, возможно, как-то связан с искаженной формой исходного *Säbä-nojan (*usasбmos6?). Все это могло быть следствием ошибок 
поздних переписчиков, которые выявляются в тексте в ряде других случаев [37, c. 119]. В случае с os $\partial s$ и $\mathcal{X} \supset 3 s$ речь может идти о двух разных источниках заимствования, показывающих *jäтӓ и * ̌̌еbӓ соответственно, поскольку передача подобных форм, судя по имеющимся данным касательно, о крайней мере тюркских заимствований в грузинском (См.: [52, s. 123]), не должна была вызвать каких-то сложностей. Одним из таких источников, что характерно, могла быть даже «Тайная история монголов» [37, с. 121, 122]

Исходя из логики автора рассматриваемой статьи в случае с Гемябеком $[28$, с. 710$]$, речь должна идти о заимствовании «тюркской» формы, но даже не *jEmä, а * ұama [28, с. 710, 711].

Действительно, в доступной литературе, - специальной и справочной, нам не удалось обнаружить случаев, демонстрирующих возможность отражения тюрк. је- через слав $2 E-$. Все известные формы заимствований из других языков демонстрируют наличие инициального $G$-, $K$ - или $\chi$ - (см., напр.: $[39$, с. $112-117])^{4}$. Иначе говоря, пришлось бы предполагать исходную форму * $g E m \ddot{a}$ или вообще * $\chi$ Етӓ, хотя, следуя Стивену Поу, должен быть именно велярный вариант * $\chi а т а ~[28$, с. 710,711$]$.

Однако длинные рассуждения автора статьи все-таки не дают ответа на

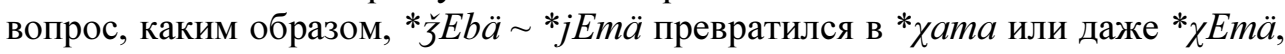
а затем в *Gemж? Если второе звено в этой схеме фонетических трансформаций, как было отмечено выше, возможно, то первое - не может вытекать ни из чего вообще. Максимум, что можно предположить, если совсем пуститься в область гипотез и фантазий, это существование в каком-нибудь арабогра-

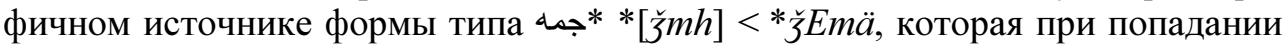
к тюркоязычному, а затем - к русскоязычному грамотею, ввиду каких-либо палеографических причин была принята за حم* * $[h m h]$ или при прочтении * $\chi E т \ddot{a}$ или даже * $\chi a т a$, в итоге превратившись в желанное * гемя-, и то, скорее, из первого, потому что пришлось бы искать дополнительные аргументы для объяснения палатализации во втором случае.

Вероятно, при сильном желании и широкой фантазии, можно было бы изыскать еще какие-либо пути объяснения столь необычной трансформации, однако, те данные, которыми мы реально располагаем, позволяют ограничиться лишь следующими рассуждениями.

Вообще для полноты как аргументации, так и контраргументации всех подобных сопоставлений следовало бы рассмотреть все возможности появления в древнерусском источнике имени *Гемябггъ, при возможности согласиться с автором статьи, что элемент бггъь, передавая оригинальное тюркское *beg, семантически эквивалентен монгольскому појаn [28, с. 711].

Инициальный $g$ - не характерен для кыпчакских языков в целом [33, c. 276-277]. В языке Codex Cumanicus, первом известном письменном памят-

\footnotetext{
${ }^{3}$ Характерно, что монгольский историк XVII в. Санан Сэцэн вообще не упоминает Джэбэ, во всех соответствующих «Тайной истории...» эпизодах называя Джэлмэ, который был совсем другим человеком [57, p. 173]. Причина этого не ясна, хотя, конечно, оставляет возможности для различных спекуляций.

${ }^{4}$ Авторы статьи выражают глубокую признательность чл.-корр. РАН, д.и.н., проф. А.В. Дыбо (Институт языкознания РАН) за возможность проконсультироваться с ней по ряду лингвистических вопросов.
} 
нике западно-кыпчакского языка, в словах с палатальным вокализмом, являющихся заимствованиями, может быть прослежено ji-> 亏̌i-, je-> 亏̌e- [43, S. 53-54], в частности, gichöv [ร̌ihöv] 'templum' при jihov id. [41, o. 158, 273, 198, 276], в случае с в giemis [క̌emis] 'fructus', при jemis id [41, о. 89, 273, 125, 276]. Это значит, что исконное *jEmä могло передаться в кыпчакском как * ̌̌Emä, и, надо отметить, в свое время И.Н. Березин мимоходом предложил оригинальное чтение Джемебек [4, с. 247]. Однако, даже если было бы так, при заимствовании в древнерусский западно-кыпчакское * з̌Еmӓ должно было дать что-то наподобие *жсмя (ср.: [12, с. 96]).

В древнерусских летописях под 1184 г. упоминаются половции Смжкове [18, стб. 389; 22, с. 9], ср.: еммякове [24, с. 27], Емаковы [25, с. 135]. Если мы принимаем отождествление этого названия с именем тюркской племенной группировки jemäk [57, p. 335; 46, p. 307; 45, p. 121], то получаем наглядный пример передачи в древнерусском языке фонетически идентичной искомому *jEmä формы, где, однако, тюрк. je-> др.-рус. e-. Другой пример, который может демонстрировать подобную закономерность: Cmeбичu < *jeti oba [46, p. $65 ; 45$, p. 113,121$]$ (ср. передачу имен, образованных от основы *jeti в более поздних источниках: [64, p. 58]). Основная часть известных тюркизмов, в древнерусском имевших инициальный $e$ - $(/ \mathrm{je} />/ \mathrm{ji} /)$, отражала адаптацию тюркского веляризованного ја- [58, р. 302; 27, с. 156; 12, с. 187-188].

Инициальный $j$ - может в кыпчакских языках редуцироваться (кыргызский, алтайский, карачаево-балкарский) [33, с. 281] и, если допустить этот процесс в западо-кыпчакском, то получившееся *jEmä $>*$ emä, исходя из примера слова с инициальным $e$ - как *Eлтоуть (упомянут под 1180 г.) [20, стб. 623] <*eltut [65, p. 333; 46, p. 306, note 55], дало бы др.-рус. *ємя.

Вместе с тем, если допустить гипотезу О. Прицака об этимологизации летописного написания имени половецкого хана (уп. в 1107 г.) Гиргень <*irgen, в древнерусском фиксируется наличие протетического инициального $g$ - при передаче, по крайней мере, иноязычного $i$ - [57, p. 334], однако эта гипотеза не имеет никаких подтверждений, как и сама этимология О. Прицака. Ср. также: < тюрк. girgin 'ласковый, вкрадчивый, дерзкий', тюрк. kirgin 'достигнувший цели', 'долженствующий достигнуть цели', монг. gürgen kürgen 'зять' [3, с. 77, 80, 83]. Этимология О. Прицака допускает что-то связанное со ср. монг. irgen с зафиксированным основным значением для ср.-монг. 'люди' (абстрактное), релятивное, ввиду чего слово приобретает более конкретные значения [31]. В источниках термин отражен в написании уйгурским шрифтом как irgen, в написании шрифтом Пагс-Па как 'irgen, в написании китайским шрифтом встречается форма yirgen, арабским письмом - hirgen, армянским письмом обозначается irkan (см.: [66, s. 158-159]). Термин представляется заимствованием из тюркской среды [62, s. 209; 42, s. 126-127]. Первая формальная аналоги - титул, встречающийся в памятниках древнетюркской рунической письменности, форме как с узким, так и широким инициальным гласным irkin (письм. $I r^{2} k I n^{2}$ ) / erkin (письм. $r^{2} k n^{2}$ ) [68, s. 259], что в сопоставлении с известными формами передачи его звучания в среднекитайском (cbl-uззинь 俟斤, пиньин. qi-jīn; ce-uзиннь 頴斤, пиньин. хіéjīn; ce-изинь 頡筋, пиньин. хіе́-jīn; и-иззинь 逸厅, пиньин. yì-jīn; и-иззинь 乙斤, пиньин. y̌̌-jīn) (см., напр.: [53, s. 90-91; 54, p. 125-126, list II]) делает возмож- 
ным видеть здесь закрытый /е̣/. Термин возводят к глаголу irk- 'собирать' [40, p. 221, 225], допускающий широкий инициальный в диалектах [32, с. 378379], ср. гомогенное карах.-уйг. irkin «'collected together in one place' and like» [40, p. 225], а также прилагательное-омоним erkin 'свободный', '(при)вольный' < *er-, cp. erk 'воля', 'сила' [32, с. 296]. Зафиксированное, по крайней мере, к 629 г., в «Синь Тан шу» 新唐書 написание названия подразделения (бу 部) племени $c u$ 霄, $\partial y$-лунь хэ-изинь 都倫紇斤 [35, с. 42, при некорректной реконструкции на с. 43-44]: пиньин. dōu-lún hé-jīn < ран. ср.-кит. *to-lwin yat-kin, позд. ср.-кит. *tиӑ-lyn xhat-kin [58, p. 81, 202, 123, 156], <*törün yerkin [53, S. 95, 124, Tab. II.3, S. 137, Tab. III.12，S. 90-91，130, Tab. II.9, S. 128-129, Tab. II.8; 54, p. 70, tabl. I.3, p. 92, tabl. III.9, p. 74, tabl. I.9, p. 73, tabl. I.8, p. 125-126, 132, list II], вторая часть которого предоставляет возможность передачи первого слога с начальным задним звонким смычным согласным $/ \gamma /$ [35, с. 43 , прим. 10], дает основание предполагать в реконструируемом звучании * үẹkän произношение на том языке, из которого китайскими авторами это слово было взято. Кроме того, реконструкция контекста всей фразы позволяет предположить сдвиг семантики в сторону значений, зафиксированных в монгольских языках (см.: [67, p. 622; 15, с. 19]). Ср., вероятно, зап.бур. этнонимы ирхидэй / эрхидэй, иркит [14, с. 44; 13, с. 149; 15, с. 19]. Гипотетичность и реконструкций, и отождествлений, а также значительный хронологический разрыв между зафиксированными формами при допустимом сближении, не дает основания ни для каких далеко идущих выводов.

Таким образом, к выше сказанному относительно форм с инициальным глухим велярным спирантом следует добавить, что нет никаких оснований говорить также и о возможности как передачи в др.-рус. *гемд- западнокыпчакского *jEmä, как и нет оснований предполагать появление формы * $g E m \ddot{a}$ $<* j E m \ddot{a}$ уже в самом западно-кыпчакском.

Подводя итоги данного исследования, хотелось бы еще раз остановиться на некоторых, на наш взгляд, важных сюжетах. Прежде всего, оба вынесенных автором на рассмотрение концептуальных положения обстоятельной критики не выдерживают: представление о действиях военных отрядов Джэбэ и Субэдэя в Иране и на Кавказе, как о завоевательном походе, не находят своего подтверждения ни в источниковедческом, ни в историческом отношении. Более того, действия этих полководцев можно достаточно четко разделить на два этапа, до и после 1220 г., в первом из которых их важнейшей целью было преследование хорезмшаха Ала ад-Дина Мухаммада, а во втором в большей степени разведка. По крайней мере, убедительного доказательства обратного, а именно завоевательного характера похода указанных войск, исторические источники, как и было показано в данной статье, не приводят. В отношении второго положения, а именно обстоятельств смерти Джэбэ и локализация данного события в работе Стивена Поу, нами, прежде всего, отмечается отсутствие лингвистической аргументации гипотезы автора при весьма ценных наблюдениях. Таким образом, в статье Стивена Поу приводятся крайне интересные, новые идеи относительно такой исторической персоналии, как Джэбэ-нойон и его военной деятельности, однако убедительных доказательств в пользу смелых авторских выводов она не содержит. Хотелось 
бы надеяться, что озвученные нами контраргументы будут замечены научным сообществом и будут иметь какое-то значение для продолжения научной дискуссии по ряду затронутых Стивеном Поу вопросов.

\section{СПИСОК ЛИТЕРАТУРЫ}

1. Анонимный грузинский «Хронограф» XIV века / Пер. со старогруз. Г.В. Цулая. М.: Ин-т этнологии и антропологии, 2005. 162 с.

2. Армянские источники о монголах: извлечения из рукописей XIII-XIV вв. / Пер. с древнеарм., предисл. и примеч. А.Г. Галстяна; [отв. ред. С.Д. Дылыков]. М.: Вост. лит., 1962. $155 \mathrm{c}$.

3. Баскаков Н.А. Тюркская лексика в «Слове о полку Игореве». М.: Наука, 1985. $208 \mathrm{c}$.

4. Березин И. Первое нашествие монголов на Россию // Журнал Министерства Народного просвещения. 1853. Ч. LXXIX. Отд. 2. С. 221-250.

5. Гиппиус А.А. К истории сложения текста Новгородской первой летописи // Новгородский исторический сборник. 1997. Вып. 6(16). С. 3-72.

6. Грузинский Хронограф (1207-1318) / Пер. с древнегруз., предисл. и коммент. П.М. Мурадяна. Ереван: Изд-во АН Армянской ССР, 1971. 252 с.

7. Картлис цховреба: история Грузии / Пер. с груз. яз.; под ред. акад. Р. Метревели. Тбилиси: Изд-во «АРТАНУДЖИ», 2008. 456 с.

8. [Кононов А.Н.] Родословная туркмен. Сочинение Абу-л-гази, хана хивинского: исследование, тексты, переводы. М.; Л. : Изд-во АН СССР, 1958. 193. 94 с.

9. Кычанов Е.И. Сведения из «Истории династии Юань» («Юань ши») о Золотой. Орде // Источниковедение истории Улуса Джучи (Золотой Орды). От Калки до Астрахани. 1223-1556. Казань: Ин-т истории АН РТ, 2001. С. 30-42.

10. Лурье Я.С. Лаврентьевская летопись - свод начала XIV в. // Труды Отдела древнерусской литературы / отв. ред. Д.С. Лихачев. Л.: Наука, 1974. Т. 29. Вопросы истории русской средневековой литературы. Памяти В.П. Адриановой-Перетц. C. 50-67.

11. Лурье Я.С. Общерусские летописи XIV-XV вв. Л.: Наука, 1976. 283 с.

12. Менгес К.Г. Восточные элементы в «Слове о полку Игореве»/ [Отв. ред. А. Н. Кононов; пер. с англ. А.А. Алексеев]. Л.: Наука, 1979. 268 с.

13. Нанзатов Б.З. Идинские буряты в XIX в.: этнический состав и расселение // Известия Иркутского государственного университета. Серия «Геоархеология. Этнология. Антропология». 2017. Т. 20. С. 136-156.

14. Нанзатов Б.3. Этногенез западных бурят (VI-XIX вв.). Иркутск: Радиан, $2005.159 \mathrm{c}$.

15. Нанзатов Б.3., Сундуева Е.В. Раннесредневековые (древнеуйгурские) этнические связи Прибайкалья с Центральной Азией (на примере группы булагатских племен «Обогони олон»)// Вестник Бурятского государственного университета. 2014. Вып. 10. Филология. Ч. 1. С. 17-20.

16. Ан-Насави Шихаб ад-Дин Мухаммад. Жизнеописание султана Джалал адДина Манкбурны / Пер., предисл., коммент., примеч. и указатели. 3.М. Буниятова. Баку: Элм, 1973. 450 c.

17. Новгородская первая летопись старшего и младшего изводов / Под ред. и с предисл. А.Н. Насонова. М.; Л.: Изд-во АН СССР, 1950. 642 с.

18. Полное собрание русских летописей. Т. 1. Изд. 2-е. Лаврентьевская летопись. Вып. 2: Суздальская летопись по Лаврентьевскому списку. Петроград: Первая Петроградская Трудовая Артель Печатников, 1927. [2] с., стб. 289-488, [2] с. 
19. Полное собрание русских летописей. Т. 1. Изд. 2-е. Лаврентьевская летопись. Вып. 3 Приложения. Продолжение Суздальской летописи по Академическому списку. Л.: Изд-во АН СССР, 1928. XVI с., стб. 489-540, с. 541-580.

20. Полное собрание русских летописей. Т. 2. Изд. 2-е. Ипатьевская летопись. СПб.: Тип. М.А. Александрова, 1908. [2] с., стб. 1-938, 87, iv с.

21. Полное собрание русских летописей. Т. 5. Изд. 2-е. Псковская вторая и Софийская первая летописи. Л.: Изд-во АН СССР, 1925. 286 с., 2 табл.

22. Полное собрание русских летописей. Т. 10. Изд. 1-е. Летописный сборник, именуемый Патриаршею или Никоновскою летописью. СПб.: Тип. Министерства внутр. дел, 1885. 6, 244 с.

23. Полное собрание русских летописей. Т. 15. Изд. 1-е. Летописный сборник, именуемый Тверскою летописью. СПб.: Тип. Леонида Демиса, 1863. 12 с., 504 стб., 1 табл.

24. Полное собрание русских летописей. Т. 18. Изд. 1-е. Симеоновская летопись. СПб.: Тип. М.А. Александрова, 1913. iii, 316 с.

25. Полное собрание русских летописей. Т. 20. Изд. 1-е. Львовская летопись. Ч. 1. СПб.: Тип. М.А. Александрова, 1910. iv, 419 с.

26. Полное собрание русских летописей. Т. 23. Изд. 1-е. Ермолинская летопись. СПб.: Тип. М.А. Александрова, 1910. v, 238 с.

27. Поппе-младший Н. О тюркских лексических заимствованиях в «Слове о полку Игореве» и «Задонщине» // Труды Отдела древнерусской литературы. СПб.: Дмитрий Буланин, 2004. T. LV. С. 153-161.

28. Поу С. Последняя кампания и смерть Джебе-нойона // Золотоордынское обозрение. 2017. Т. 5, № 4. С. 698-725. DOI: 10.22378/2313-6197.2017-5-4.698-725

29. Рашид-ад-дин. Сборник летописей. М.; Л.: АН СССР, 1952. Т. 1. Кн. 1. / Пер. с перс. Л.А. Хетагурова; редакция и прим. А.А. Семенова. 221 с.

30. Рашид-ад-дин. Сборник летописей. М.; Л.: АН СССР, 1952. Т. 1. Кн. 2./ Пер. с перс. О.И. Смирновой; прим. Б.И. Панкратова и О.И. Смирновой; редакция А.А. Семенова. 315 с.

31. Рыкин П.О. Социальная группа и ее название в среднемонгольском языке: понятия irgen и oboq // Антропологический форум. 2004. № 1. С. 179-209.

32. Севортян Э.В. Этимологический словарь тюркских языков (Общетюркские и межтюркские основы на гласные). М.: Наука, 1974. 767 с.

33. Сравнительно-историческая грамматика тюркских языков. Региональные реконструкции / отв. ред. Э.Р. Тенишев. М.: Наука, 2002. 767 с.

34. Тимохин Д.М. Использование монгольскими войсками тактики хашара в период завоевания государства Хорезмшахов (1219-1221 гг.) // Батыр. 2011. № 1(2). C. $33-39$.

35. Тишин B.B. Некоторые заметки по исторической этнонимике Центральной Азии: $c u$ 霄 или бай-cu 白霄 // Общество и государство в Китае / Редкол.: А.И. Кобзев и др. М.: ИВ РАН, 2016 (Ученые записки Отдела Китая ИВ РАН. Вып. 20). Т. XLVI. Ч. 1. С. 41-52. $557 \mathrm{c}$.

36. Храпачевский Р.П. Военная держава Чингисхана. М.: АСТ: ЛЮКС, 2005.

37. Цулая Г.В. Грузинская книжная легенда о Чингис-хане // Советская этнография. 1973. № 5. С. 114-122.

38. ЦЦулая Г.В. Джалал ад-Дин в оценке грузинской летописной традиции // Летописи и хроники. 1980. В.Н. Татищев и изучение русского летописания / Ред. Б.А. Рыбаков и др. М.: Наука, 1981. С. 112-128.

39. Шипова Е.Н. Словарь тюркизмов в русском языке / отв. ред. А.Н. Кононов. Алма-Ата: Наука, 1976. 444 с. 
Тимохин Д.М., Тишин В.В. О новых тенденциях в изучении истории монгольских завоеваний...

40. Clauson G. An Etymological Dictionary of Pre-Thirteenth-Century Turkish. Oxford: Clarendon Press, 1972. xlviii, 989 p.

41. Codex Cumanicus / Ed. by G. Kuun; with the prolegomena to the Codex Cumanicus by Louis Ligeti. Budapest: Magyar Tudományos Akadémia Könyvtár, 1981. 54, cxxxiv, 395 oldal.

42. Doerfer G. Türkische und mongolische Elemente im Neupersischen unter besonderer Berücksichtigung älterer neupersischer Geschichtsquellen vor allem der Mongolen- und Timuridenzeit. Wiesbaden: Franz Steiner Verlag, 1963. Bd. I. Mongolische Elemente im Neupersischen (Akademie der Wissenschaften und der Literatur: Veröffentlichungen der Orientalischen Komission. Bd. XVI). xlviii, 557 S.

43. Gabain A. von. Die Sprache des Codex Cumanicus// Philologiae Turcicae fundamenta: iussu et auctoritate Unionis Universae Studiosorum Rerum Orientalium, auxilio et opera Unitarum Nationum Educationis Scientiae Culturae Ordinis, una cum praestantibus Turcologis / Ed. J. Deny, K. Grønbech, H. Scheel, Z.V. Togan. T. 1. [Wiesbaden: Franz Steiner], 1959. P. 46-73.

44. Genghis Khan. The History of the World-Conqueror by 'Ala-ad-Din 'Ata-Malik Juvaini / Transl. from the text of Mirza Muhammad Qazvini by J.A. Boyle; with a new introd. and bibliogr. by D.O. Morgan. Manchester: Manchester University Press, 1997. lxvii, $763 \mathrm{pp}$.

45. Golden P.B. Cumanica IV: The Tribes of Cuman-Qıpčaq // Archivum Eurasiae Medii Aevi. 1995-1997. Vol. IX. P. 99-122.

46. Golden P.B. The Polovci Dikii // Harvard Ukrainian Studies. 1979-1980. № 3-4. P. 296-309.

47. Fennell J. The Tatar Invasion of 1223: Source Problems // Forschungen zur osteuropäischen Geschichte. 1980. Bd. 27. P. 18-31.

48. Histoire des campagnes de Gengis Khan, Chêng-wou ts'in-tchêng lou / Traduit et annoté: P. Pelliot et L. Hambis. Leiden: E.J. Brill, 1951. T. I. xxvii, 485 p.

49. Histoire des Mongols et des Tatares, par Aboul-Ghâzi Béhâdour Khân / publiée, traduite et annotée par le baron Desmaisons. Saint-Pétersbourg: Imprimerie de l'Académie Impériale des sciences, 1871. T. I. Texte. ${ }^{\top \wedge \tau}$, ii $\mathrm{p}$.

50. Histoire des Mongols et des Tatares, par Aboul-Ghâzi Béhâdour Khân / publiée, traduite et annotée par le baron Desmaisons. Saint-Pétersbourg: Imprimerie de l'Académie Impériale des sciences, 1874. T. II. Traduction. iv, 384 p.

51. Jackson P. JABA // Encyclopaedia Iranica / ed. by Ehsan Yar-Shater. London: Routledge \& Kegan Paul, 2007. P. 305.

52. Janashia M. Gürcü Dilindeki Türkçe Kökenli Özel İsimler // Ankara Üniversitesi Dil ve Tarih-Coğrafya Fakültesi Türkoloji Dergisi. 2010. Cilt 17. Sayı 2. P. 115-129.

53. Kasai Yukiyo. Die alttürkischen Wörter aus Natur und Gesellschaft in chinesischen Quellen (6. und 9. Jh.). Der Ausgangsterminus der chinesischen Transkription $t \bar{u}$ jué 突厥 // "Die Wunder der Schöpfung”. Mensch und Natur in der türksprachigen Welt / Hgs. B. Heuer, B. Kellner-Heinkele, C. Schönig. Würzburg: Ergon-Verlag, 2012 (Istanbuler Texte und Studien. Bd. 9). S. 81-141.

54. Kasai Yukiyo. The Chinese Phonetic Transcriptions of Old Turkish Words in the Chinese Sources from $6^{\text {th }}-9^{\text {th }}$ Century: Focused on the Original Word Transcribed as $t \bar{u}$ jué 突厥 // 内陸アジア言語の研究 [Nairiku ajia gengo no kenkyū] / Studies on the Inner Asian languages. 2014. Vol. XXIX. P. 57-135.

55. Marquart J. Über das Volkstum der Komanen // Bang, W., Marquart, J. Ostturkische Dialektstudien. Berlin: Weidmannsche Buchhandlung, 1914 (Abhandlungen der Königlichen Gesellschaft der Wissenschaften zu Göttingen, Philologisch-historische Klasse, Neue Folge. Bd. XIII. № 1). S. 25-238. 
56. Ögel B. Sino-Turcica: Çingiz Han ve Çin'deki hanedanının Türk müşavirleri. İstanbul, 2002 (IQ Kültür Sanat Yayıncılık: 30; Araştırma-İnceleme Dizisi: 13) [Repr. of: Tai-pei, 1964]. xxii, $412 \mathrm{~s}$.

57. Pelliot P. A propos des Comans // Journal Asiatique. 1920. XI série. T. XV. № 1. P. 125-185.

58. Poppe N.J. Jr. A Survey of Studies of Turkic Loan-Words in the Russian Language // Central Asiatic Journal. 1966. Vol. 11. No. 4. P. 287-310.

59. Pow S. The Last Campaign and Death of Jebe Noyan // Journal of the Royal Asiatic Society. Cambridge. 2017. Vol. 27. Is. 1. P. 31-51.

60. Pritsak O. The Polovcians and Rus // Archivum Eurasiae Medii Aevi. 1982. T. II. P. 321-380.

61. Pulleyblank E.G. A Lexicon of Reconstructed Pronunciation in Early Middle Chinese, Late Middle Chinese, and Early Mandarin. Vancouver: UBC Press, 1991. vii, $488 \mathrm{p}$.

62. Ramstedt G.J. Kalmückisches Wörterbuch. Helsinki, 1935 (Lexica Societatis Fenno-Ugricae. III). xxx, $560 \mathrm{~S}$.

63. Rashiduddin Fazlullah's Jami'u't-tawarikh. A Compendium of Chronicles: A History of the Mongols / Transl. and Annotation by Wheeler M. Thackston. Pt. 1. Cambridge, MA: Harvard University, Department of Near Eastern Languages and Civilizations, 1998 (Sources of Oriental Languages \& Literatures 45; Central Asian Sources IV). xliv, $244 \mathrm{p}$.

64. Rásonyi L. Les noms de nombre dans l'anthroponymie turque // Acta Orientalia Academiae Scientiarum Hungaricae. 1961. T. XII. Fasc. 1-3. P. 45-71.

65. Rásonyi L. Sur quelques catégories de noms de personnes en turc// Acta Linguistica Hungarica. 1953. T. III. P. 323-352.

66. Rybatzki $V$. Die Personennamen und Titel der Mittelmongolischen Dokumente. Eine lexikalische Untersuchung. Helsinki: Yliopistopaino Oy, 2006 (Publications of the Institute for Asian and African Studies. 8). xxxv, $841 \mathrm{~S}$.

67. Starostin S.A., Dybo A.V., Mudrak O.A. An Etymological Dictionary of Altaic Languages. Leiden; Boston: Brill, 2003. Pt. I. A-K (Handbook of Oriental Studies. Section eight, Central Asia; Vol. 8/1). P. 1-858.

68. Şirin User H. Köktürk ve Ötüken Uygur Kağanlığı Yazıtları. Söz Varlığı İncelemesi. Konya, 2009 (Kömen Yayınları 32; Türk Dili Dizisi 1). 548 s.

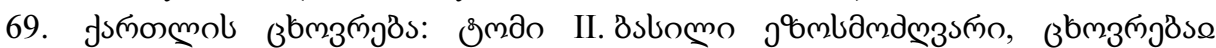

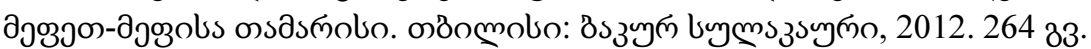

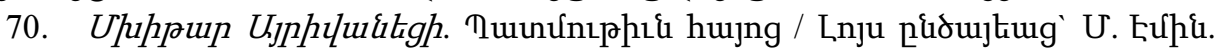

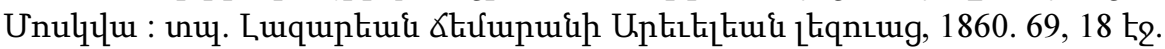

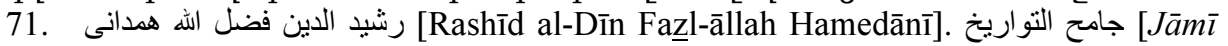
al-Tawārīkh]. Publ. and comment. by Moḥammad Roshan, Mostafa Mousavi [نشر البرز : تهران [به تصحيح و تحشيه :محمد روشن؛ مصطفى موسوى [Tehrān] [Nashr ālbarz],

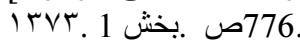

Сведения об авторах: Дмитрий Михайлович Тимохин - кандидат исторических наук, старший научный сотрудник ФГБУН Института востоковедения РАН (107031, Рождественка, 12, Москва, Российская Федерация). E-mail: horezm83@mail.ru

Владимир Владимирович Тишин - кандидат исторических наук, старший научный сотрудник Института монголоведения, буддологии и тибетологии СО РАН (670047, ул. Сахьяновой, 6, Улан-Удэ, Российская Федерация). E-mail: tihij511@mail.ru 
Тимохин Д.М., Тишин В.В. О новых тенденциях в изучении истории монгольских завоеваний..

\section{REFERENCES}

1. Anonimnyi gruzinskii "Khronograf" 14 veka [Anomymous Georgian Chronograph of the fourteenth century]. Tsulaya G.V. (trans.). Moscow, Institute of Ethnology and Antropology, 2005. 162 p. (In Russian)

2. Armianskie istochniki o mongolakh: izvlecheniia iz rukopisei 13-14 vv. [Armenian Sources on the Mongols: Extracts from the Manuscripts of the thirteenth and fourteenth centuries]. Galstyan A.G. (trans.). Moscow, Oriental Lierature, 1962. 155 p. (In Russian)

3. Baskakov N.A. Tiurkskaia leksika v "Slove o polku Igoreve" [A Turkic Lexion in the "Igor's Tale"]. Moscow, Nauka Publ., 1985. 208 p. (In Russian)

4. Berezin I. Pervoe nashestvie mongolov na Rossiiu [The First Mongol Invasion of Russia]. Zhurnal Ministerstva Narodnogo prosveshcheniia [Journal of the Ministry of Public Education]. 1853. Part 79, Is. 2, pp. 221-250. (In Russian)

5. Gippius A.A. K istorii slozheniia teksta Novgorodskoi pervoi letopisi [On the History of Formation of the Text of the Novgorod First Chronicle]. Novgorodskii istoricheskii sbornik [Novgorod Historical Collection]. 1997. Vol. 6(16), pp. 3-72. (In Russian)

6. Gruzinskii Khronograf (1207-1318) [Georgian Chronograph (1207-1318)]. Muradyan P.M. (trans.). Erevan, Academy of Sciences of Armenian SSSR, 1971. 252 p. (In Russian)

7. Kartlis tskhovreba: istoriia Gruzii [Kartlis Tskhovreba: A History of Georgia]. Metreveli R. (trans.). Tbilisi, “ARTANUDZhI” Press, 2008. 456 p. (In Russian)

8. [Kononov A.N.] Rodoslovnaia turkmen. Sochinenie Abu-l-Gazi, khana khivinskogo: issledovanie, teksty, perevody [The Genealogy of Turkmens. A Compositin of Abu'l-Ghazi of Khiva: Analysis, Text, Translation]. Moscow; Lenibgrad, Akademiya nauk SSSR Publ., 1958. 193, 94 p. (In Russian)

9. Kychanov E.I. Svedeniia iz "Istorii dinastii Iuan" ("Iuan' shi”) o Zolotoi Orde [Evidence from the "History of Yuan Dinasty" on the Golden Horde]. Istochnikovedenie istorii Ulusa Dzhuchi (Zolotoi Ordy). Ot Kalki do Astrakhani. 1223-1556 [A Study of Sources of the ulus of Jochi (Golden Horde): From Kalka to Astrakhan. 1223-1556]. Kazan, Sh.Marjani Institute of History of Tatarstan Academy of Sciences, 2001, pp. 30-42. (In Russian)

10. Lurje Ia.S. Lavrent'evskaia letopis' - svod nachala 14 v. [Laurentian Chronicle: A Composition of the early fourteenth century]. Trudy Otdela drevnerusskoi literatury [Proceedings of the Department of Old Russian Literature]. Likhachev D.S. (ed.). Leningrad, Nauka, 1974. Vol. 29. Voprosy istorii russkoi srednevekovoi literatury. Pamiati V.P. Adrianovoi-Peretts [Problems of a History of Russian Literature, Dedicated to the Memory of V.P. Adrianova-Peretts], pp. 50-67. (In Russian)

11. Lurje Ia.S. Obshcherusskie letopisi 14-15vv. [Common Russian Chronicles of the fourteenth and fifteenth centuries]. Leningrad, Nauka Publ., 1976. 283 p. (In Russian)

12. Menges K.G. Vostochnye elementy v "Slove o polku Igoreve" [Oriental Elements in the "Igor's Tale"]. Kononov A.N. (ed.), Alekseev A.A. (transl.). Leningrad, Nauka, 1979. 268 p. (In Russian)

13. Nanzatov B.Z. Idinskie buriaty v 19 v.: etnicheskii sostav i rasselenie [Ida Buryats in the nineteenth century: An Ethnical Composition and Territory of Settlement]. Izvestiia Irkutskogo gosudarstvennogo universiteta. Seriia "Geoarkheologiia. Etnologiia. Antropologiia" [Reports of the Irkutsk State University. Series "Geoarchaeology. Ethnology. Anthropology"]. 2017. Vol. 2, pp. 136-156. (In Russian) 
14. Nanzatov B.Z. Etnogenez zapadnykh buriat (6-19vv.) [An Ethnogenesis of Western Buryats (from the sixth to the nineteenth century)]. Irkutsk, Radian Press, 2005. 159 p. (In Russian)

15. Nanzatov B.Z., Sundueva E.V. Rannesrednevekovye (drevneuigurskie) etnicheskie sviazi Pribaikal'ia s Tsentral'noi Aziei (na primere gruppy bulagatskikh plemen "Obogoni olon") [Early Medieval (Ancient Uighur) Ethnic Ties of Baikal Region with Inner Asia (based the Example of Group of Bulagat Tribes "Obogoni Olon")]. Vestnik Buriatskogo gosudarstvennogo universiteta [Bulletin of Buryat State University]. 2014. Vol. 10. Philology. Part 1, pp. 17-20. (In Russian)

16. An-Nasavi Shihab al-Din Muhammad. Zhizneopisanie sultana Dzhalal ad-Dina Mankburny [The Life of Sultan Jalal al-Din Mankburny]. Buniyatov Z.M. (trans.). Baku, Elm, 1973. 450 p. (In Russian)

17. Novgorodskaia pervaia letopis' starshego i mladshego izvodov [Novgorod First Chronicle according to the Oldest and Younger Izvods]. Nasonov A.N. Moscow; Leningrad, Akademiya nauk SSSR Publ., 1950. 642 p. (In Old Russian)

18. Polnoe sobranie russkikh letopisei [Complete Collection of Russian Chronicles]. Vol. 1. $2^{\text {nd }}$ ed. Lavrent'evskaia letopis' [Laurentian Chronicle]. Pt. 2. Suzdal'skaia letopis' po Lavrent'evskomu spisku [Suzdal Chronicle according to the Laurentain Maniscript]. Petrograd, Pervaia Petrogradskaia Trudovaia Artel' Pechatnikov, 1927. [2] p., cols 289488, [2] p. (In Old Russian)

19. Polnoe sobranie russkikh letopisei [Complete Collection of Russian Chronicles]. Vol. 1. $2^{\text {nd }}$ ed. Lavrent'evskaia letopis' [Laurentian Chronicle]. Pt. 3. Prilozheniia. Prodolzhenie Suzdal'skoi letopisi po Akademicheskomu spisku [Appendix. A Continuation of the Suzdal Chronicle according to the Academical Manuscript]. Leningrad, Akademiya nauk SSSR Publ., 1928. xvi p., cols 489-540, pp. 541-580. (In Old Russian)

20. Polnoe sobranie russkikh letopisei [Complete Collection of Russian Chronicles]. Vol. 2. $2^{\text {nd }}$ ed. Ipat'evskaia letopis' [Hypathian Chronicle]. St. Petersburg, Tipography of M.A. Aleksandrov, 1908. [2] p., cols 1-938, 87, iv p. (In Old Russian)

21. Polnoe sobranie russkikh letopisei [Complete Collection of Russian Chronicles]. Vol. 5. $2^{\text {nd }}$ ed. Pskovskaia vtoraia i Sofiiskaia pervaia letopisi [Pskov Second and Sophian First Chronicles]. Leningrad, Akademiya nauk SSSR Publ., 1925. 286 p., 2 tabl. (In Old Russian)

22. Polnoe sobranie russkikh letopisei [Complete Collection of Russian Chronicles]. Vol. 10. $1^{\text {st }}$ ed. Letopisnyi sbornik, imenuemyi Patriarsheiu ili Nikonovskoiu letopis'iu [Collection of Chronicles called the Patriarch's or Nikon Chronicle]. St. Petersburg, Tipography of Ministry of Internal Affairs, 1885. 6, 244 p. (In Old Russian)

23. Polnoe sobranie russkikh letopisei [Complete Collection of Russian Chronicles]. Vol. 15. $1^{\text {st }}$ ed. Letopisnyi sbornik, imenuemyi Tverskoiu letopis'iu [Collection of Chronicles called the Tver Chronicle]. St. Petersburg, Tipography of. Leonid Demis, 1863. 12 p., 504 cols, 1 tabl. (In Old Russian)

24. Polnoe sobranie russkikh letopisei [Complete Collection of Russian Chronicles]. Vol. 18. $1^{\text {st }}$ ed. Simeonovskaia letopis' [Simeon Chronicle]. St. Petersburg, Tipography of M.A. Aleksandrov, 1913. iii, 316 p. (In Old Russian)

25. Polnoe sobranie russkikh letopisei [Complete Collection of Russian Chronicles]. T. 20. $1^{\text {st }}$ ed. L'vovskaia letopis' [Lvov's Chronicle]. Part 1. St. Petersburg, Tipography of M.A. Aleksandrov. iv, 419 p. (In Old Russian)

26. Polnoe sobranie russkikh letopisei [Complete Collection of Russian Chronicles]. T. 23. $1^{\text {st }}$ ed. Ermolinskaia letopis' [Ermolin's Chronicle]. St. Petersburg, Tipography of M.A. Aleksandrov, 1910. v, 238 p. (In Old Russian)

27. Poppe-junior N. O tiurkskikh leksicheskikh zaimstvovaniiakh v "Slove o polku Igoreve" i "Zadonshchine" [On the Turkic Borrowings in the "Igor's Tale" and "Zadonshchina"]. Trudy Otdela drevnerusskoi literatury [Proceedings of the Department of 
Тимохин Д.М., Тишин В.В. О новых тенденциях в изучении истории монгольских завоеваний...

Old Russian Literature]. St. Petersburg, Dmitrii Bulanin Press, 2004. Vol. 40, pp. 153-161. (In Russian)

28. Pow S. The Last Campaign and Death of Jebe Noyan. Zolotoordynskoe obozrenie $=$ Golden Horde Review. 2017. Vol. 5, no. 4, pp. 698-725. DOI: 10.22378/23136197.2017-5-4.698-725 (In Russian)

29. Rashid al-Din. Sbornik letopisei [A Collection of Chronicles]. Moscow; Leningrad, Akademiya nauk SSSR Publ., 1952. Vol. 1. Part 1. / Khetagurov L.A. (trans.). 221 p. (In Russian)

30. Rashid al-Din. Sbornik letopisei [A Collection of Chronicles]. Moscow; Leningrad, Akademiya nauk SSSR Publ., 1952. T. 1. Pt. 2 / O.I. Smirnova (trans.). 315 p. (In Russian)

31. Rykin P.O. Sotsial'naia gruppa i ee nazvanie v srednemongol'skom iazyke: poniatiia irgen i oboq [A Social Group and Its Nomination in the Middle Mongolic: the terms irgen and oboq]. Antropologicheskii forum [Antropological Forum]. 2004, no. 1, pp. 179-209. (In Russian)

32. Sevortian E.V. Etimologicheskii slovar' tiurkskikh iazykov (Obshchetiurkskie i mezhtiurkskie osnovy na glasnye) [An Etymological Dictionary of Turkic Languages (Common Turkic and Interturkic stems starting with vowels)]. Moscow, Nauka Publ., 1974. 767 p. (In Russian)

33. Sravnitel'no-istoricheskaia grammatika tiurkskikh iazykov. Regional'nye rekonstruktsii [A Comparative-Historical Grammar of Turkic Languages. Regional Reconstructions]. Tenishev E.R. (ed.). Moscow, Nauka Publ., 2002. 767 p. (In Russian)

34. Timokhin D.M. Ispol'zovanie mongol'skimi voiskami taktiki khashara $\mathrm{v}$ period zavoevaniia gosudarstva Khorezmshakhov (1219-1221 gg.) [The Execution of the Tactics of Khashar by the Mongol Troops during Their Conquest of the Khwarezmshah Empire in 1219-1221]. Batyr. 2011, no 1(2), pp. 33-39. (In Russian)

35. Tishin V.V. Nekotorye zametki po istoricheskoi etnonimike Tsentral'noi Azii: si 霄 ili bai-si 白霄 [Some Remarks on the Ethnonymy of Inner Asia: Xi 霄 and Bái-xí 白霄]. Obshchestvo i gosudarstvo $v$ Kitae [A Society and the State in China]. Kobzev A.I. (ed.). Moscow, Institute of Oriental Studies, 2016. Vol. 46. Part 1, pp. 41-52. (In Russian)

36. Khrapachevskii R.P. Voennaia derzhava Chingiskhana [A Military Polity of Chinggis Khan]. Moscow, AST, LIuKS, 2005. 557 p. (In Russian)

37. Tsulaya G.V. Gruzinskaia knizhnaia legenda o Chingis-khane [Georgian Book Legend about Chinggis Khan]. Sovetskaia etnografiia [Soviet Ethnography]. 1973. No. 5, pp. 114-122. (In Russian)

38. Tsulaya G.V. Dzhalal ad-Din v otsenke gruzinskoi letopisnoi traditsii [Jalal alDin in the Assessment of the Georgian Chronicle Tradition]. Letopisi i khroniki. 1980. V.N. Tatishchev i izuchenie russkogo letopisaniia [Annals and Chronicles. 1980. V.N. Tatishchev and the Study of Russian Chronicles]. Rybakov B.A. (ed.). Moscow, Nauka, 1981, pp. 112-128. (In Russian)

39. Shipova E.N. Slovar' tiurkizmov v russkom iazyke [A Vocabulary of Turkic Borrowings in Russian]. Alma-Ata, Nauka Publ., 1976. 444 p. (In Russian)

40. Clauson G. An Etymological Dictionary of Pre-Thirteenth-Century Turkish. Oxford, Clarendon Press, 1972. xlviii, 989 p.

41. Codex Cumanicus. Kuun G (ed.), Ligeti L. (not.). Budapest, Magyar Tudományos Akadémia Könyvtár, 1981. 54, cxxxiv, 395 oldal. (In Hungarian)

42. Doerfer G. Türkische und mongolische Elemente im Neupersischen unter besonderer Berücksichtigung älterer neupersischer Geschichtsquellen vor allem der Mongolen- und Timuridenzeit. Wiesbaden, Franz Steiner Verlag, 1963. Bd. I. Mongolische Elemente im Neupersischen (Akademie der Wissenschaften und der Literatur: Veröffentlichungen der Orientalischen Komission. Bd. XVI). xlviii, 557 p. (In German) 
43. Gabain A. von. Die Sprache des Codex Cumanicus. Philologiae Turcicae fundamenta: iussu et auctoritate Unionis Universae Studiosorum Rerum Orientalium, auxilio et opera Unitarum Nationum Educationis Scientiae Culturae Ordinis, una cum praestantibus Turcologis. Vol. 1. Deny J., Grønbech K., Scheel H., Togan Z.V. (eds.). [Wiesbaden, Franz Steiner], 1959, pp. 46-73. (In German)

44. Genghis Khan. The History of the World-Conqueror by 'Ala-ad-Din 'Ata-Malik Juvaini. Boyle J.A. (trans), Morgan D.O. (pref.). Manchester, Manchester University Press, 1997. 1xvii, 763 p.

45. Golden P.B. Cumanica IV: The Tribes of Cuman-Q1pčaq. Archivum Eurasiae Medii Aevi. 1995-1997. Vol. 9, pp. 99-122.

46. Golden P.B. The Polovci Dikii. Harvard Ukrainian Studies. 1979-1980. No 3-4, pp. 296-309.

47. Fennell J. The Tatar Invasion of 1223: Source Problems. Forschungen zur osteuropäischen Geschichte. 1980. Bd. 27, pp. 18-31.

48. Histoire des campagnes de Gengis Khan, Chêng-wou ts'in-tchêng lou. Pelliot P., Hambis L. (trans.). Leiden, E.J. Brill, 1951. Vol. I. xxvii, 485 p. (In French)

49. Histoire des Mongols et des Tatares, par Aboul-Ghâzi Béhâdour Khân. Desmaisons J.J.P. (publ.). Saint-Pétersbourg, Imprimerie de l'Académie Impériale des sciences, 1871. T. I. Texte. r^ז, ii p. (In French)

50. Histoire des Mongols et des Tatares, par Aboul-Ghâzi Béhâdour Khân. Desmaisons J.J.P. (trans.). St. Pétersbourg, Imprimerie de l'Académie Impériale des sciences, 1874. Vol. II. Traduction. iv, 384 p. (In French)

51. Jackson P. JABA. Encyclopaedia Iranica. Ehsan Yar-Shater (ed.). London, Routledge \& Kegan Paul, 2007, p. 305.

52. Janashia M. Gürcü Dilindeki Türkçe Kökenli Özel İsimler. Ankara Üniversitesi Dil ve Tarih-Coğrafya Fakültesi Türkoloji Dergisi. 2010. Vol. 17. Part 2, pp. 115-129. (In Turkish)

53. Kasai Yukiyo. Die alttürkischen Wörter aus Natur und Gesellschaft in chinesischen Quellen (6. und 9. Jh.). Der Ausgangsterminus der chinesischen Transkription tū jué 突厥. “Die Wunder der Schöpfung”. Mensch und Natur in der türksprachigen Welt. Heuer B., Kellner-Heinkele B., Schönig C. (eds.). Würzburg, Ergon-Verlag, 2012 (Istanbuler Texte und Studien. Bd. 9), pp. 81-141. (In German)

54. Kasai Yukiyo. The Chinese Phonetic Transcriptions of Old Turkish Words in the Chinese Sources from $6^{\text {th }}-9^{\text {th }}$ Century: Focused on the Original Word Transcribed as tū jué 突厥. 内陸アジア言語の研究 [Nairiku ajia gengo no kenkyū]. Studies on the Inner Asian languages. 2014. Vol. 29, pp. 57-135.

55. Marquart J. Über das Volkstum der Komanen. In: Bang, W., Marquart, J. Ostturkische Dialektstudien. Berlin, Weidmannsche Buchhandlung, 1914 (Abhandlungen der Königlichen Gesellschaft der Wissenschaften zu Göttingen, Philologisch-historische Klasse, Neue Folge. Bd. XIII. No 1), pp. 25-238. (In German)

56. Ögel B. Sino-Turcica: Çingiz Han ve Çin'deki hanedanının Türk müşavirleri. İstanbul, 2002 (IQ Kültür Sanat Yayıncılık: 30; Araştırma-İnceleme Dizisi: 13) [Repr. of: Tai-pei, 1964]. xxii, 412 p. (In Turkish)

57. Pelliot P. A propos des Comans. Journal Asiatique. 1920. 11 série. Vol. 15, no. 1, pp. 125-185. (In French)

58. Poppe N.J. Jr. A Survey of Studies of Turkic Loan-Words in the Russian Language. Central Asiatic Journal. 1966. Vol. 11, no. 4, pp. 287-310.

59. Pow S. The Last Campaign and Death of Jebe Noyan. Journal of the Royal Asiatic Society. Cambridge, 2017. Vol. 27. Is. 1, pp. 31-51.

60. Pritsak O. The Polovcians and Rus. Archivum Eurasiae Medii Aevi. 1982. Vol. 2, pp. $321-380$. 
61. Pulleyblank E.G. A Lexicon of Reconstructed Pronunciation in Early Middle Chinese, Late Middle Chinese, and Early Mandarin. Vancouver, UBC Press, 1991. vii, $488 \mathrm{p}$.

62. Ramstedt G.J. Kalmückisches Wörterbuch. Helsinki, 1935 (Lexica Societatis Fenno-Ugricae. III). xxx, 560 p. (In German)

63. Rashiduddin Fazlullah's Jami'u't-tawarikh. A Compendium of Chronicles: A History of the Mongols. W.M. Thackston (trans.). Pt. 1. Cambridge, MA, Harvard University, Department of Near Eastern Languages and Civilizations, 1998 (Sources of Oriental Languages \& Literatures 45; Central Asian Sources IV). xliv, 244 p.

64. Rásonyi L. Les noms de nombre dans l'anthroponymie turque. Acta Orientalia Academiae Scientiarum Hungaricae. 1961. Vol. 12. Fasc. 1-3, pp. 45-71. (In French)

65. Rásonyi L. Sur quelques catégories de noms de personnes en turc. Acta Linguistica Hungarica. 1953. Vol. 3, pp. 323-352. (In French)

66. Rybatzki V. Die Personennamen und Titel der Mittelmongolischen Dokumente. Eine lexikalische Untersuchung. Helsinki, Yliopistopaino Oy, 2006 (Publications of the Institute for Asian and African Studies. 8). xxxv, 841 p. (In German)

67. Starostin S.A., Dybo A.V., Mudrak O.A. An Etymological Dictionary of Altaic Languages. Leiden; Boston, Brill, 2003. Pt. I. A-K (Handbook of Oriental Studies. Section eight, Central Asia; Vol. 8/1), pp. 1-858.

68. Şirin User H. Köktürk ve Ötüken Uygur Kă̆anlı̆̆l Yazıtlart. Söz Varlı̆̆l Incelemesi. Konya, 2009 (Kömen Yayınları 32; Türk Dili Dizisi 1). 548 p. (In Turkish)

69. Kartlis Tskhovreba [Life of Kartli]. Vol. II. Basili Ezosmodzghvari, Tskhovrebae Mepet-Mepisa Tamarisi [History of the King of Kings Tamar]. Tbilisi, Bak'ur Sulak'auri, 2012, 264 p. (In Georgian).

70. Mkhit'ar Ayrivanets'i. Patmut'iwn hayots'. Emin M. (publ.). Moscow, Lazarean chemarani Arevelean lezuats' [Lazarev Lyceum for Oriental Languages], 1860. 69, 18 p. (In Armenian)

71. Rashīd al-Dīn Fažl-āllah Hamedānī. Jāmī al-Tawārīkh. Roshan M., Mousavi M. (publ. and comment.). Tehrān, Nashr ālbarz, 1373. Vol. 1. 776 p. (In Persian)

About the authors: Dmitry M. Timokhin - Cand. Sci. (History), Senior research fellow for the Institute of Oriental studies of the RAS (12, Rozhdestvenka, Moscow 107031, Russian Federation). E-mail: horezm83@mail.ru

Vladimir V. Tishin - Cand. Sci. (History), Senior research fellow of the Institute for Mongolian, Buddhist and Tibetan Studies of the Siberian Branch of the RAS (6, Sakhyanovoy Str., Ulan-Ude 670047, Russian Federation). E-mail: tihij-511@mail.ru 